\title{
INTEGRAL STUDY OF ATRAZINE BEHAVIOR IN FIELD LYSIMETERS IN ARGENTINEAN HUMID PAMPAS SOILS
}

\author{
Susana Hang ${ }^{1 *}$, Adrián Andriulo² ${ }^{2}$ Carolina Sasal ${ }^{2}$, Mirtha M. Nassetta ${ }^{3}$, Silvina Portela², \\ and Ana I. Cañas ${ }^{3}$
}

\begin{abstract}
Atrazine behavior during crop maize (Zea mays L.) production in soils of Argentine humid pampas was investigated. Lysimeters ( 3.3 x 3.3 x 1.4 m) with a Typic Argiudoll (Pergamino) and others with a Typic Hapludoll (Junín) were monitored for drainage water content and atrazine concentrations in soil and water. Soil profiles were sampled in four depths in three dates, and water drainage pooled in four periods. Most of atrazine loss in drainage occurred within $30 \mathrm{~d}$ of atrazine application being $0.13 \%$ and $0.03 \%$ of the total atrazine applied for Pergamino and Junín, respectively. Under laboratory conditions half-life average in both profiles was $16 \mathrm{~d}$. Atrazine extractable residues (AER) in lysimeters showed differences in quantity and distribution between both profiles. Extractable residues were 25.7 (Pergamino) and $69.4 \mathrm{~g} \mathrm{ha}^{-1}$ (Junín). At the $30^{\text {th }}$ day of application, AER represented $25 \%$ of total AER in Junín and $88 \%$ in Pergamino in the first $30 \mathrm{~cm}$. Occurrence of preferential flow through the $\mathrm{B}_{\mathrm{t}}$ horizon (Pergamino) may explain differences detected. High proportion of AER in Junín profile suggests low atrazine affinity and should be followed through time in order to evaluate actual stability of these residues and if they constitute a potential risk for aquifers.
\end{abstract}

Key words: atrazine extractable residues, preferential flow, half-life, contamination risk.

\section{INTRODUCTION}

Atrazine (6-chloro- $\mathrm{N}^{2}$-ethyl- $\mathrm{N}^{4}$-isopropyl-1,3,5triazine-2,4-diamine) has been studied for more than 50 years, however, still it is difficult to reach a complete understanding of its behavior and establish the determinant characteristics and periods with greatest vulnerability of the environment to this herbicide.

Retention, transformation, and transport are the three mechanisms that regulate atrazine evolution in the soil. The study of those mechanisms in isolation has allowed the parameterization of each mechanism through indexes: determination coefficient, $\mathrm{Kd}$; dissipation rate, $k$; and retardation factor, Rf. Currently, there are accessible and complete databases of those parameters (Tomlin, 2003).

Various environmental factors such as temperature,

${ }^{1}$ Universidad Nacional de Córdoba, Facultad de Ciencias Agropecuarias, CC 509 5000, Córdoba, Argentina.

"Corresponding author (shang@agro.unc.edu.ar).

${ }^{2}$ Instituto Nacional de Tecnología Agropecuaria INTA, B2700WAA,

Pergamino, Buenos Aires, Argentina.

${ }^{3}$ Ceprocor, ACC-SE 5164, Córdoba, Argentina.

Received: 10 March 2009.

Accepted: 07 July 2009. water content, oxygen status, soil type, soil organic matter, atrazine concentration, $\mathrm{N}$ fertilization, crop and soil management has also allowed the determination of variation ranges of $\mathrm{Kd}$ and $k$ indexes (Stolpe and Shea, 1995; Barriuso and Houot, 1996; Koskinen and Clay, 1997; Azevedo et al., 2000a; Di et al., 2001). However, phenomena like preferential flow can lead to herbicide behavior in a soil profile that is different to that expected from its edaphic properties only (Pivetz and Steenhuis, 1995).

The complexity of these interactions is usually partially overcome through modeling (Azevedo et al., 2000b; Asare et al., 2001; Noshadi et al., 2002; Pollock et al., 2002), establishing field scale studies (Sadeghi and Isensee, 1992; Schoen et al., 1999; Azevedo et al., 2000a). Use of lysimeters allows for integral studies of pesticide behavior in soil. In studies at semi-field scale with partially controlled conditions, is possible to incorporate aspects related to crop such as crop development, fertilization, crop sequence, method of water supply, cultivation systems (Dousset et al., 1995; Isensee and Sadeghi, 1996; 1997; Clay et al., 1998; Cherrier et al., 2005). Many of these studies have been conducted with irrigation, thus allowing for determination of changes in the atrazine residues availability in terms of the time passed since application and the water supply (Beck et al., 1996). 
The study was conducted during the maize crop production in plots with lysimeters in two characteristic profiles of the region, maintaining local use strategies and management. In order to understand the fate of atrazine in soils of the humid pampas of Argentina with an integral study, the objectives were to identify the critic period during a crop of maize to transport down atrazine in two typic soil profiles, and to identify the soil properties more related to atrazine behavior.

\section{MATERIALS AND METHODS}

\section{Area of study and lysimeters}

The study was conducted at the Pergamino Experimental Station of the Instituto Nacional de Tecnología Agropecuaria (INTA) $\left(33^{\circ} 51^{\prime} \mathrm{S}\right.$; 60 $\left.40^{\circ} \mathrm{W}\right)$. An experimental device composed of six lysimetric boxes of reinforced concrete (closed and gravity lysimeters) (Figure 1). The lysimeters were made in 1968. Dimensions of each (one) lysimetric box are $3.3 \times 3.3 \times 1.4 \mathrm{~m}$ of depth. Three lysimeters were mechanical filled with a Typic Argiudoll (Pergamino) and the other three were filled with a Typic Hapludoll (Junín), according the natural horizon sequences. Profiles were placed on a filtering bed made in sand and gravel which carried the water into a tube to collect the drainage. This device has been used since its installation with different rotations of maize, soybean (Glycine max [L.] Merr.), and sunflower (Helianthus annuus L.)

Soil properties were determined after sampling in plots near to lysimeters with corresponding soil profile. The soils were air-dried and sieved to $2 \mathrm{~mm}$. Particle size distribution among sand, silt and clay fractions was done by sieving and sedimentation. The soil $\mathrm{pH}$ was determined in water (soil:water, 1:2), organic carbon (OC) content by wet combustion (Walkey and Black), cationic exchangeable capacity (CEC) was done by saturation with $1 \mathrm{~N}$ ammonium acetate at $\mathrm{pH} 7$, water- holding capacity (WHC) was determined by pressure cooker, permanent wilting point (PWP) was determined by pressure membrane. All these techniques are described in Sparks (1996). The physical and chemical properties of each soil profile are shown in Table 1 . Soil bulk density was done in situ by means the core method (Blake and Hartge, 1986).

Since 2001 was conducted a maize-soybean rotation under non-tillage system. Both sets of lysimeters were planted with maize ('Dekalb 752 Bt') on 29 September 2001. At planting fertilization with $100 \mathrm{~kg} \mathrm{ha}^{-1}$ diammonium phosphate was done, and $60 \mathrm{~kg} \mathrm{ha}^{-1}$ urea was applied at $4^{\text {th }}$ leaf. The cropping was harvested after $110 \mathrm{~d}$, on 5 March 2002. The grain yield in average was $10000 \mathrm{~kg} \mathrm{ha}^{-1}$ and there were no significant differences between the two soil types.

Weather parameters such as temperature and rainfall were recorded with an automatic weather station situated $50 \mathrm{~m}$ from the device.

Study of atrazine retention and transport in lysimeters A dose of $4 \mathrm{~L} \mathrm{ha}^{-1}$ atrazine (TRAC 50 FL Atanor, p.a. 50\%, San Nicolás, Argentina) was applied at pre-emergence of maize crop. Soil samples were taken at four depths: $0-5,5-30,30-100,100-120 \mathrm{~cm}$ in each lysimeter with a soil auger of $1 \mathrm{~cm}$ of inner diameter. The auger was cleaned with pure alcohol between the depth samples. The sampling dates were: Pre-planting, $30 \mathrm{~d}$ after atrazine application, and $110 \mathrm{~d}$ after atrazine application. The soil samples were air dried and sieved through $2 \mathrm{~mm}$ and stored at $-18^{\circ} \mathrm{C}$ until their analysis.

Drainage water was sampled when present. Effluents were pooled into four periods: pre-planting-atrazine application (P1); 0-17 d after application (P2); 18-30 d after application (P3); and 31-110 d after application (P4). In each drainage period proportional mix samples were prepared with a final volume of $2 \mathrm{~L}$, stored at $5{ }^{\circ} \mathrm{C}$ in glass flasks until their analysis.

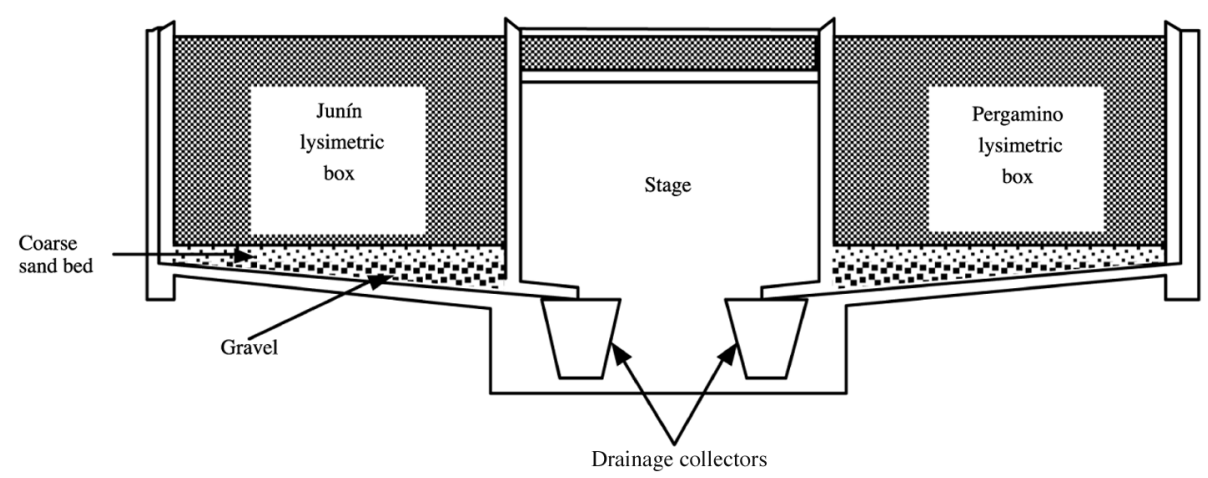

Figure 1. Lysimeter design. 
Table 1. Physical and chemical properties of two soil profiles.

\begin{tabular}{|c|c|c|c|c|c|c|c|c|}
\hline \multirow{3}{*}{$\begin{array}{l}\text { Soil } \\
\text { Soil classification } \\
\text { Horizon } \\
\end{array}$} & \multicolumn{3}{|c|}{ Pergamino } & & \multicolumn{3}{|c|}{ Junín } & \multirow[b]{3}{*}{$\mathbf{C}$} \\
\hline & \multicolumn{3}{|c|}{ Typic Argiudoll } & & \multicolumn{3}{|c|}{ Typic Hapludoll } & \\
\hline & \multicolumn{2}{|c|}{$\mathbf{A}+\mathbf{B A}$} & \multirow{2}{*}{$\frac{\text { Bt }}{30-100}$} & \multirow{2}{*}{$\frac{\text { BC }}{100-120}$} & \multicolumn{2}{|c|}{$\mathbf{A}$} & \multirow{2}{*}{$\frac{\text { B }}{30-100}$} & \\
\hline Depth, cm & $0-5$ & $5-30$ & & & $0-5$ & $5-30$ & & $100-120$ \\
\hline Clay, $\mathrm{g} \mathrm{kg}^{-1}$ & 216 & 206 & 388 & 190 & 105 & 192 & 180 & 104 \\
\hline Sand, $\mathrm{g} \mathrm{kg}^{-1}$ & 200 & 238 & 177 & 251 & 500 & 490 & 486 & 590 \\
\hline Silt, $\mathrm{g} \mathrm{kg}^{-1}$ & 584 & 556 & 435 & 559 & 395 & 318 & 334 & 306 \\
\hline Textural class & \multicolumn{2}{|c|}{ — Silty loam - } & Silty clay loam & Silty loam & \multicolumn{3}{|c|}{ _ Sandy loam } & \\
\hline WHC, $\mathrm{g} \mathrm{kg}^{-1}$ & 289 & 270 & 276 & 254 & 238 & 235 & 198 & 157 \\
\hline PWP, $\mathrm{g} \mathrm{kg}^{-1}$ & 146 & 154 & 18.5 & 139 & 109 & 89 & 95 & 90 \\
\hline $\mathrm{pH}$ & 6.2 & 6.6 & 6.9 & 7.6 & 6.3 & 6.4 & 6.7 & 7.4 \\
\hline $\mathrm{OC}, \mathrm{g} \mathrm{kg}^{-1}$ & 25 & 16 & 5.2 & 4.1 & 22.0 & 15.1 & 5.8 & 2.3 \\
\hline $\mathrm{CEC}, \mathrm{cmol}_{\mathrm{c}} \mathrm{kg}^{-1}$ & 21.0 & 20.4 & 30.8 & 25.6 & 14.4 & 15.0 & 13.1 & 12.0 \\
\hline Bulk density, $\mathrm{Mg} \mathrm{m}^{-3}$ & 1.10 & 1.30 & 1.35 & 1.25 & 1.10 & 1.21 & 1.29 & 1.25 \\
\hline
\end{tabular}

WHC: water holding capacity; PWP: permanent wilting point; $\mathrm{pH}$ : soil:water, 1:2; OC: organic carbon; CEC: cation exchange capacity.

\section{Atrazine degradation studies under laboratory conditions}

Soils were characterized by their potential capacity to degrade atrazine. Twenty grams of air dried sample obtained form each soil depth were incubated in the dark at $28 \pm 1{ }^{\circ} \mathrm{C}$ at constant moisture content (80\% of field capacity), $5 \mathrm{~mL}\left(30 \mathrm{mg} \mathrm{L}^{-1}\right)$ of atrazine solution was added to soil samples placed in hermetic flasks to a final herbicide concentration of $7.5 \mu \mathrm{g} \mathrm{g}^{-1}$ of soil per flask. After $0,7,14,28,56$ days of incubation three replicates and a blank (soil + water, without atrazine) were extracted from each soil depth. The samples were frozen until their processing.

Atrazine daily dissipation rate was calculated from the atrazine degradation studies under laboratory conditions. Atrazine half-life was calculated using first order equation:

$$
\mathrm{C}_{\mathrm{t}}=\mathrm{C}_{0} \mathrm{e}^{-k t}
$$

where $\mathrm{C}_{\mathrm{t}}$ is the concentration of atrazine at time $t ; \mathrm{C}_{0}$, the initial atrazine concentration; $k$ the dissipation rate and $t$, the time of measurement.

\section{Chemical analysis of atrazine extractable residues}

Atrazine was extracted from soil with $20 \mathrm{~mL}$ of acetonitrile:water (90:10). Centrifuge tubes were agitated for $2 \mathrm{~h}$ at room temperature $\left(20 \pm 2{ }^{\circ} \mathrm{C}\right.$ approximately). Soil extracts were purified using $3 \mathrm{~mL}$ of bencenesulfonic acid cartridges (Bakerbond SPE aromatic sulfonic acid $3 \mathrm{~mL}$, [500 mg], J.T. Baker, Phillipsburg, New Jersey, USA) under vacuum (Visiprep Solid Phase Extraction Vacuum Manifold, Supelco, Bellefonte, Pennsylvania, USA). Cartridges were conditioned with $3 \mathrm{~mL}$ of aqueous solution of $1 \%$ acetic acid. From each soil, $5 \mathrm{~mL}$ extract were mixed with $25 \mathrm{~mL}$ of aqueous solution of $1 \%$ acetic acid and then aspirated through the cartridges at $5 \mathrm{~mL}$ $\mathrm{min}^{-1}$. The cartridges were successively washed with 1 $\mathrm{mL}$ acetonitrile, $3 \mathrm{~mL}$ MilliQ water and finally with $1 \mathrm{~mL}$ $0.1 \mathrm{M} \mathrm{K}_{2} \mathrm{HPO}_{4}$. An atrazine elution was performed with 5 $\mathrm{mL}$ of a mixture of acetonitrile: $\mathrm{K}_{2} \mathrm{HPO}_{4} 0.1 \mathrm{M}(1: 1)$. The eluate was recovered in $5 \mathrm{~mL}$ volumetric flasks and filled to $5 \mathrm{~mL}$ with acetonitrile: $\mathrm{K}_{2} \mathrm{HPO}_{4} 0.1 \mathrm{M}$ solution.

Atrazine quantification was performed by high performance liquid chromatography (HPLC) using a Waters appliance equipped with automatic injection and a 996-Photodiode Array, using an LC 10AS pump, a UV-Vis SPD 10 VP detector, an SIL 10 ADVP automatic injector, an SCL 10 A controller and Millenium 03 software (Waters 2690, Milford, Massachusetts, USA). Samples were injected using acetonitrile: $\mathrm{K}_{2} \mathrm{HPO}_{4} 0.05 \mathrm{M}$ (40:60) as mobile phase and measurements were performed at $254 \mathrm{~nm}$. Based on previous assays, it was observed that the percentage of recovery and the quantification limit of this procedure ranged between 95 and $105 \%$ and $0.04 \mu \mathrm{g}$ $\mathrm{mL}^{-1}$, respectively (Cañas et al., 2000).

Extractable atrazine in soils was expressed in concentration units $\left(\mu \mathrm{g} \mathrm{kg}^{-1}\right)$ and content per unit surface $\left(\mathrm{kg} \mathrm{ha}^{-1}\right)$, applying the mean values of apparent density and at each depth. Atrazine in water was expressed in concentration units $\left(\mu \mathrm{g} \mathrm{L}^{-1}\right)$ and in quantity $\left(\mu \mathrm{g} \mathrm{ha}^{-1}\right)$ from the mean concentrations and the volume of drained water accumulated in each drainage period.

\section{Experimental design and statistical analysis}

The experimental design was randomized complete blocks with three repetitions and two treatments. Double ANOVA were carried out. Comparison of means between treatments was performed by Duncan test $(\mathrm{P}<0.05)$ and orthogonal contrasts were done. The statistical program used was InfoStat (2003). 


\section{RESULTS AND DISCUSSION}

\section{Drainage and atrazine leaching losses}

Most of the drainage occurred during the first $30 \mathrm{~d}$, with significant differences between soil profiles (Table 2). In this first crop stage the drainage was $81 \%$ and $85 \%$ of the total recovered for Pergamino (213 mm) and Junín (256 $\mathrm{mm})$, respectively. These drainage levels coincided with a high volume of rainfall, soils with high water content (80\% field capacity) and a maize crop status with low evapotranspiration capacity.

Atrazine concentration in drainage water for both soil profiles is shown in Figure 2. Atrazine was not detected in the period pre-planting-application (P1). After its application it was detected in all subsequent periods. Most of atrazine leaching losses occurred during the first $30 \mathrm{~d}$ after application (P2 y P3) corresponding to the $0.13 \%$ of the atrazine input for Pergamino and the $0.03 \%$ for Junín. At the time of atrazine application the soil showed a high water content, approximately $80 \%$ of the field capacity in both profiles. The high water content of the soil favors atrazine transport, associated with gravity drainage (Beck et al., 1996), piston-type water flow (Sorenson et al., 1994) reduces atrazine retention (Koskinen and Rochette, 1996). Besides, the condition of "fresh residues" favors atrazine mobility (Beck et al., 1996; Neurath et al., 2004; Cherrier et al., 2005). In P4 (31-110 d after application) these percentages decreased to 0.01 and $0.005 \%$ for Pergamino and Junín, respectively. Significant differences between both profiles were not found, probably due to the high variability among lysimeters of each profile.

Atrazine mean concentration in the drainage was of $1.98 \mu \mathrm{g} \mathrm{L}^{-1}$ for the Pergamino soil and $0.58 \mu \mathrm{g} \mathrm{L}^{-1}$ for the Junín soil, that is to say that the atrazine concentration average was below the maximum contamination level (MCL) of atrazine in drinking water set by the Environmental Protection Agency of the United States (USEPA) $\left(3.0 \mu \mathrm{g} \mathrm{L}^{-1}\right)$. However, for Pergamino in the $\mathrm{P} 3$ period, the mean value of atrazine concentration in drainage water was over the MCL $\left(3.3 \pm 2.3 \mu \mathrm{g} \mathrm{L}^{-1}\right)$. The higher concentration and quantity of atrazine recovered

Table 2. Rainfall and cumulative drainage during crop maize cycle grouped in two periods $(0-30$ and $30-110$ days).

\begin{tabular}{llcl}
\hline & \multicolumn{3}{c}{ Period $(\mathbf{d})$} \\
\cline { 2 - 4 } & $\mathbf{0 - 3 0}^{\mathbf{1}}$ & $\mathbf{3 0 - 1 1 0}$ & Total \\
\hline Rainfall, mm & 299 & 372 & 671 \\
Pergamino drainage, $\mathrm{mm}$ & $172 \mathrm{a}^{2}$ & $41 \mathrm{a}$ & $213 \mathrm{a}$ \\
Junín drainage, mm & $218 \mathrm{~b}$ & $38 \mathrm{a}$ & $256 \mathrm{a}$ \\
\hline
\end{tabular}

130 days: Planting-4 $4^{\text {th }}$ leaf; $30-110$ days: $4^{\text {th }}$ leaf-harvest.

${ }^{2}$ Different letters indicate significant differences according to Duncan test $(\mathrm{P}<0.05)$.

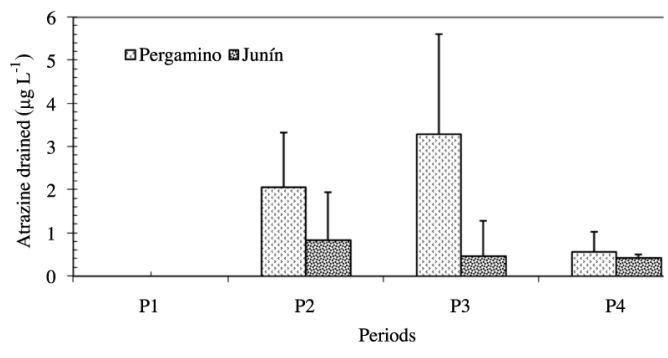

Figure 2. Atrazine concentration in the effluents pooled into four application periods: P1: preplanting; P2: 0-17 d; P3: 18-30 d; P4: 31-110 d.

from drainages during the $\mathrm{P} 2+\mathrm{P} 3$ periods for Pergamino compared to Junín suggest the incidence of various factors on atrazine transportation, such as the soil hydric status, the crop phenologic status, amount of rainfall and their proximity to the herbicide application. The incidence of these factors has been noted by others authors (Logan et al., 1994; Kalita et al., 2006).

On the other hand, preferential flow would partly explain why Pergamino profile, whose edaphic characteristics favor atrazine retention, had the highest herbicide leaching losses. Atrazine mobility in soils with clay texture related to preferential flow phenomena has been described in numerous works (Sorenson et al., 1993; 1994; Azevedo et al., 2000a; Sadeghi et al., 2000). Bundt et al. (2001) point out that fast transport of water and solutes in soil occurs in most soils, and that an important characteristic of preferential flow is the by-pass of solutes to a big portion of the soil matrix. One of the forms of preferential flow is due to a non-homogeneous infiltration (Edwards et al., 1993) like the occurrence of the argilic horizon $\left(\mathrm{B}_{\mathrm{t}}\right)$ in the Pergamino profile.

\section{Atrazine extractable residues in soil}

In pre-planting sampling atrazine extractable residues of previous applications were not found in any of the studied depths. Concentration of atrazine extractable residues recovered at 30 and $110 \mathrm{~d}$ in both profiles is shown in Table 3. Statistical analysis is shown together with the atrazine values recovered for each factor (profile-depthdate). In both sampling dates, the highest concentration was recorded in the first soil depth $(0-5 \mathrm{~cm})$. The total concentration of atrazine in the Pergamino profile was higher than in Junín, at the $30^{\text {th }}$ day as in the $110^{\text {th }}$ day; however, it was only significantly different in the first period. Both profiles showed a higher concentration of atrazine extractable residues at the $30^{\text {th }}$ day $(\mathrm{P}<0.01)$. After $30 \mathrm{~d}$, the extractable residues distribution differed only significantly at $100-120 \mathrm{~cm}$ depth. After $110 \mathrm{~d}$, it was only possible to quantify atrazine in the first $30 \mathrm{~cm}$ in the Pergamino profile and in the first $5 \mathrm{~cm}$ in Junín. Below 
Table 3. Atrazine extractable residues in four horizons of two soil profiles in three sampling dates (application dose $4 \mathrm{~L} \mathrm{ha}^{-1}$ TRAC 50 FL Atanor).

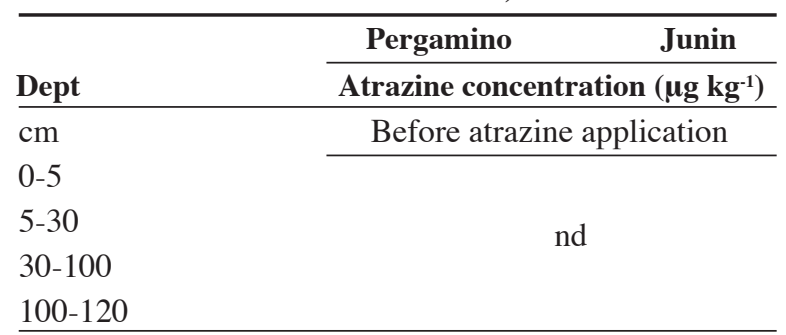

\begin{tabular}{lcc}
\hline & \multicolumn{2}{c}{30 days $^{1}$} \\
\cline { 2 - 3 } $0-5$ & $20.6 \pm 4.3 \mathrm{a}^{2}$ & $7.3 \pm 3.8 \mathrm{c}$ \\
$5-30$ & $3.5 \pm 0.4 \mathrm{c}$ & $4.4 \pm 5.8 \mathrm{~cd}$ \\
$30-100$ & $\mathrm{nd}^{4}$ & $5.3 \pm 2.5 \mathrm{~cd}$ \\
$100-120$ & $1.2 \pm 2.0 \mathrm{c}$ & $1.7 \pm 1.4 \mathrm{~d}$ \\
\hline Total atrazine & $25.3 \pm 3.9 \mathrm{aA}^{3}$ & $18.7 \pm 8.2 \mathrm{bA}$ \\
\hline & \multicolumn{2}{c}{110 days } \\
\hline residues extractable & $14.4 \pm 16.7 \mathrm{~b}$ & $1.0 \pm 1.8 \mathrm{dd}$ \\
$5-5$ & $0.1 \pm 0.2 \mathrm{~d}$ & $\mathrm{nd}$ \\
$30-100$ & $\mathrm{nd}$ & $\mathrm{nd}$ \\
$100-120$ & $\mathrm{nd}$ & $\mathrm{nd}$ \\
\hline
\end{tabular}

\begin{tabular}{lll}
\hline $\begin{array}{l}\text { Total atrazine } \\
\text { residues extractable }\end{array}$ & $14.5 \pm 1.7 \mathrm{aB}$ & $1.12 \pm 1.1 \mathrm{aB}$
\end{tabular}

nd: non-detected.

30 days: planting- $4^{\text {th }}$ leaf; $30-110$ days: $4^{\text {th }}$ leaf-harvest.

${ }^{2}$ Different small letters indicate significant differences according to Duncan test $(\mathrm{P}<0.01)$.

${ }^{3}$ Different small letters indicate significant differences $(\mathrm{P}<0.01)$ between profiles at the same sampling date.

Capital letters indicate significant differences according to Duncan test $(\mathrm{P}<0.01)$ between sampling dates at the same profile.

these depths atrazine was only detected but below the quantification limit $\left(0.01 \mu \mathrm{g} \mathrm{kg}^{-1}\right)$.

Junín profile presented less vertical variation in the atrazine extractable residues distribution than Pergamino profile. This difference in extractable residues distribution was more evident expressed as total amount of atrazine extractable residues (Table 4). Amount of atrazine extractable residues in each profile recovered at the $30^{\text {th }}$ day were 25.7 and $69.4 \mathrm{~g} \mathrm{ha}^{-1}$ for Pergamino and Junín, respectively.

Approximately $88 \%$ (22.6 g atrazine $\left.\mathrm{ha}^{-1}\right)$ was recovered in the $30 \mathrm{~cm}$ topsoil in the Pergamino profile, while in Junín only was the $25 \%$ (17.3 $\mathrm{g}$ atrazine ha-1). In Junín, 94\% (68.0 $\mathrm{g}$ atrazine ha $\left.{ }^{-1}\right)$ of the total amount of atrazine extractable residue was recovered in the first $100 \mathrm{~cm}$. Amounts of atrazine recovered in both profiles in the upper $30 \mathrm{~cm}$ of the soil suggest similar behavior in both depths. These records agree with previous studies that show that atrazine accumulates from 36 to $54 \mathrm{~cm}$ of depth, depending on the edaphic profile characteristics (Dousset et al., 1995; Clay et al., 2000). Asare et al.
(2001) determined by means of models that the mass centre of the atrazine distribution profile ranged on 23.8$49.4 \mathrm{~cm}$. Total organic carbon (OC) and clay in the $30 \mathrm{~cm}$ topsoil are 854 and $696 \mathrm{t} \mathrm{ha}^{-1}$ for Pergamino and Junín, respectively, and could partially explain the higher total of atrazine extractable residues for Pergamino than Junín, due to that both components have high atrazine retention capacity and the hysteresis of the process have been demonstrated in several works (Barriuso et al., 1992; Benoit and Preston, 2000).

However, significant differences were detected in atrazine extractable residues in the $30-100 \mathrm{~cm}$ depth. Lowest atrazine extractable residues concentration was recovered at Argilic horizon $\left(\mathrm{B}_{\mathrm{t}}\right)$ in Pergamino profile at $30 \mathrm{~d}(\mathrm{P}<0.01)$. In both profiles in the $30-100 \mathrm{~cm}$ depth, the OC content was similar, $49.2 \mathrm{t} \mathrm{ha}^{-1}$ in Pergamino and $52.4 \mathrm{t} \mathrm{ha}^{-1}$ in Junín, but while Pergamino soil presented $3666.6 \mathrm{t}_{\text {clay }} \mathrm{ha}^{-1}$, Junín soil has $1625.4 \mathrm{t}$ clay ha-1 ${ }^{-1}$. This difference is related to the presence of argilic horizon in the Pergamino profile that affects soil properties such as structure, porous distribution, etc.

The greater recovery of atrazine extractable residues in horizon $B_{w}$ (Junín) than in $B_{t}$ (Pergamino) suggests that $\mathrm{B}_{\mathrm{w}}$ horizon had higher atrazine retention capacity as extractable residues than $B_{t}$ horizon (Pergamino) associated to the absence of a rapid water flux in the Junín profile. On the other hand, the rapid water flow through the argilic horizon $\left(\mathrm{B}_{\mathrm{t}}\right)$ could favor the elimination of poorly retained residues or directly to avoid the atrazine retention.

On the other hand, the $\mathrm{B}_{\mathrm{t}}$ horizon behavior would be related with the dual effect of clay content on atrazine retention. Edaphic characteristics favour formation of non-extractable residues. Hang et al. (2005) working with profiles with pedologic characteristics similar to the ones in this study, determined a high proportion of nonextractable residues in an argilic horizon, developing in the first $7 \mathrm{~d}$ more than $80 \%$ of the total amount developed in $56 \mathrm{~d}$. Extractable and non-extractable residues are pools of atrazine related to the extraction method (Lerch et al.,

Table 4. Atrazine extractable residues in four horizons of two soil profiles, Pergamino (Typic Argiudoll) and Junín (Typic Haplustoll) recovered after 30 days of atrazine application (application dose $4 \mathrm{~L} \mathrm{ha}^{-1}$ TRAC 50 FL Atanor).

\begin{tabular}{lcrrr}
\hline & \multicolumn{4}{c}{ Atrazine } \\
\cline { 2 - 5 } Depth & \multicolumn{2}{c}{ Pergamino } & \multicolumn{2}{c}{ Junín } \\
\hline $\mathbf{c m}$ & $\mathbf{g ~ h a}^{-1}$ & $\%$ & $\mathbf{g ~ h a}^{-1}$ & $\%$ \\
$0-5$ & 11.3 & 44 & 4.0 & 6 \\
$5-30$ & 11.4 & 44 & 13.3 & 19 \\
$30-100$ & - & - & 47.9 & 69 \\
$100-120$ & 3.0 & 12 & 4.3 & 6 \\
Total & 25.7 & 100 & 69.4 & 100 \\
\hline
\end{tabular}


1999) that is to say; the absence of atrazine extractable residues in $\mathrm{B}_{t}$ horizon in Pergamino profile could be associated to occurrence of non-extractable residues (Hang et al., 2005).

\section{Half-life and daily dissipation rate}

The average value of $\mathrm{t}_{1 / 2}$ was $16 \mathrm{~d}$ in both profiles (Table 5). Dissipation rate decreased with depths in the Junín profile, the opposite happened with the half-life. Pergamino on the other hand, showed greater variability, and the argilic horizon $\left(\mathrm{B}_{\mathrm{t}}\right)$ showed the lowest atrazine daily dissipation rate and correspondingly the highest $\mathrm{t}_{1 / 2}$ value.

\section{Mass balance}

Mass balance between the amount of initial atrazine input and the amount of the atrazine recovered in soil and water is shown in Table 6. Due to the high variability among lysimeters, the mass balance was calculated separately for each one of them. The percentage of atrazine input quantified at the $30^{\text {th }} \mathrm{d}$ was $1.4 \pm 0.5 \%$ for Pergamino and $3.5 \pm 1.2 \%$ for Junín. At the end of the maize cycle these percentages decreased to $0.4 \pm 0.4 \%$ and $0.003 \pm 0.002 \%$, respectively. After $30 \mathrm{~d}$ of it application, 98.6 and $96.5 \%$ of the initial atrazine input for Pergamino and Junín, respectively, was not recovered.

Atrazine accelerate mineralization is a process detected in soils where atrazine application is frequently used (Barriuso and Houot, 1996; Hang et al., 2005; 2007a). This process is due to development of adapted microflora induced by atrazine application, and atrazine is mineralized until carbon dioxide in very short periods (Zablotowicz et al., 2006; Hang et al., 2007a).

On the other hand, non-extractable residues (bound residues) are considered atrazine dissipation processes (Clay and Koskinen, 1997; Hang et al., 2003; 2007b). Sorenson et al. $(1993 ; 1994)$ working with ${ }^{14} \mathrm{C}$-atrazine in lysimeters determined that the remaining radioactivity in the profile after 16 mo was $75 \%$ in a clay soil and $80 \%$ in a sandy soil. In our study, which was conducted in a period of 110 $\mathrm{d}$ it was observed that the highest proportion of recovered atrazine was quantified during the first $30 \mathrm{~d}$ in the drainage water as well as in the extractable residues in the soil.

Table 5. Atrazine dissipation rate, $k\left(d^{-1}\right)$ and half-life, $t_{1 / 2}$ (d) in four layers of two soil profiles.

\begin{tabular}{lcrlcr}
\hline & \multicolumn{2}{c}{ Pergamino } & & \multicolumn{2}{c}{ Junín } \\
\cline { 2 - 3 } \cline { 5 - 6 } Depth & $\boldsymbol{k}$ & $\mathbf{t}_{1 / 2}$ & & $\boldsymbol{k}$ & $\mathbf{t}_{1 / 2}$ \\
\hline $\mathrm{cm}$ & $\mathrm{d}^{-1}$ & $\mathrm{~d}$ & & $\mathrm{~d}^{-1}$ & $\mathrm{~d}$ \\
$0-5$ & $0.066 \pm 0.008$ & 10 & & $0.096 \pm 0.002$ & 7 \\
$5-30$ & $0.073 \pm 0.009$ & 9 & & $0.070 \pm 0.004$ & 10 \\
$30-100$ & $0.026 \pm 0.005$ & 27 & & $0.038 \pm 0.002$ & 18 \\
$100-120$ & $0.063 \pm 0.005$ & 11 & & $0.030 \pm 0.006$ & 23 \\
\hline
\end{tabular}

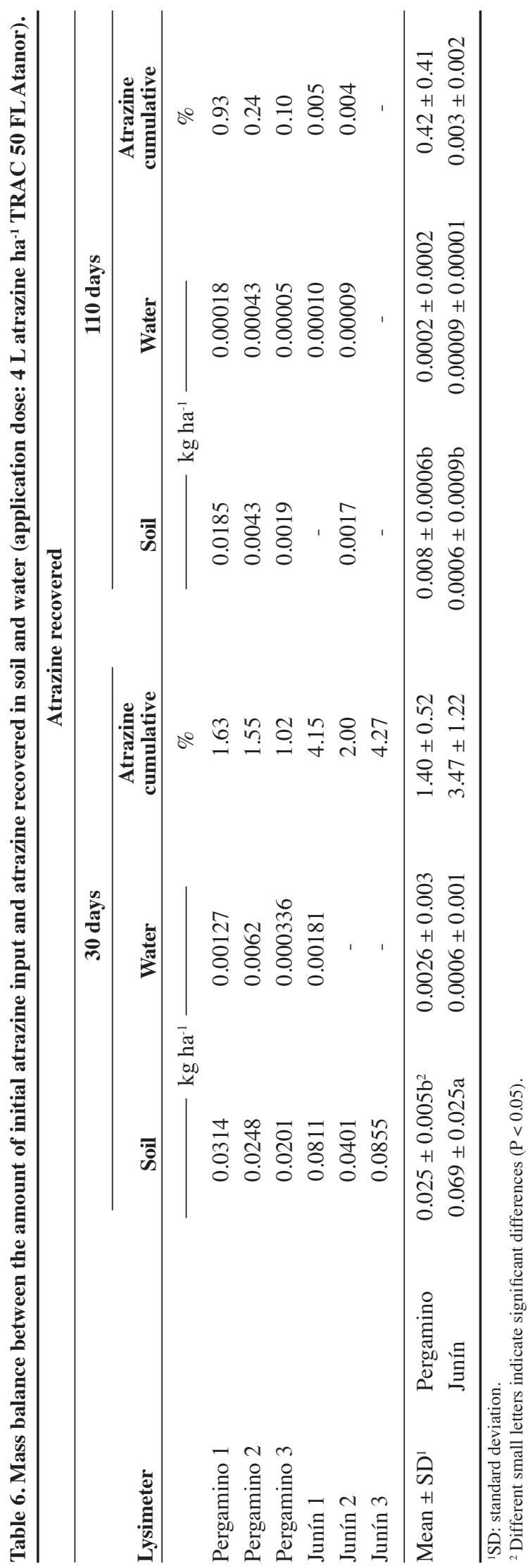




\section{CONCLUSIONS}

The results show that atrazine transport decreases from its application time. Most of atrazine loss in drainage water occurred within $30 \mathrm{~d}$ of atrazine application. Therefore, the critical period for the aquifer can be associated with precipitation events close to atrazine application (before and after) and the early growing season.

Moreover, similarities in atrazine behavior between profiles were observed up to the first $30 \mathrm{~cm}$, while below this depth significant differences were found. The occurrence of preferential flow through the $B_{t}$ horizon allowed atrazine concentration in drainage water to be higher in the profile of silty clay texture than in the profile of sandy loam texture $\left(3.10^{-3} \mathrm{vs} .6 .10^{-4} \mathrm{~kg}\right.$ de atrazine ha- $\left.{ }^{-1}\right)$. In the profile with sandy loam texture the great amount of recovered extractable residues between $30-100 \mathrm{~cm}$ suggests low atrazine affinity in this horizon and should be followed through time in order to evaluate the actual stability of these residues and if they constitute a potential risk for aquifers. Although, volume of water drained in the first $30 \mathrm{~d}$ for Pergamino was approximately $21 \%$ lower than the one in Junín, in terms of the amount of atrazine recovered in drainage for the same period, Pergamino surpassed Junín in $73 \%$, which indicates that the higher water volume drained in Junín did not compensate for the lower concentration of leaching losses in this soil.

\section{ACKNOWLEDGEMENTS}

This investigation was supported by FONCYT (Cod. 08-08054) "Contaminación de las aguas subterráneas por la producción intensiva de granos en la zona núcleo maicera" (INTA-FCA-UNC).

\section{RESUMEN}

Estudio integral del comportamiento de atrazina en lisímetros de campo en suelos de la pampa húmeda Argentina. Se estudió el comportamiento de atrazina durante el ciclo de un cultivo de maíz (Zea mays L.) en suelos de la pampa húmeda Argentina. Se monitoreó el total de agua drenada y la concentración de atrazina en suelo y agua, mediante el uso de seis lisímetros (3.3 x 3.3 x $1.4 \mathrm{~m}$ ) tres de ellos llenados con un Argiudoll Típico (Pergamino) y otros tres con un Hapludoll Típico (Junín). Se tomaron muestras de cuatro horizontes en cada perfil de suelo en tres fechas y el agua drenada se agrupó en cuatro períodos. La mayor parte de las pérdidas de atrazina en el drenaje ocurrieron dentro de los primeros 30 días desde la aplicación de atrazina. Los porcentajes recuperados respecto de la cantidad inicial aplicada fueron $0.13 \%$ and $0.03 \%$ para Pergamino y Junín, respectivamente. La vida media para ambos perfiles y cada uno de los horizontes fue determinada en condiciones de laboratorio siendo en promedio de 16 días. Se detectaron diferencias en la cantidad y la distribución de los residuos extractables de atrazina (REA) entre los dos perfiles de suelo. Mientras que en el perfil Pergamino la cantidad total de REA fue de $25.7 \mathrm{~g} \mathrm{ha}^{-1}$ para el perfil Junín fue de $69.4 \mathrm{~g} \mathrm{ha}^{-1}$ (Junín). A los 30 días de la aplicación los REA obtenidos en el perfil de Junín representaron el $25 \%$ del total recuperado y el $88 \%$ en el perfil de Pergamino. En ambos perfiles estos porcentajes se recuperaron de los primeros $30 \mathrm{~cm}$. Las diferencias detectadas en el perfil de Pergamino podrían estar asociadas a la presencia de un horizonte $\mathrm{B}_{\mathrm{t}}$ con vías de flujo preferencial. La mayor cantidad de REA en el perfil de Junín sugiere baja afinidad de atrazina y debiera ser estudiado a lo largo del tiempo a fin de evaluar la real estabilidad de estos residuos y si constituyen un potencial riesgo para los acuíferos.

Palabras clave: residuos extractables de atrazina, flujo preferencial, vida media, riesgo de contaminación.

\section{LITERATURE CITED}

Asare, D.K., T.W. Sammis, D. Smeal, H. Zhang, and D.O. Sitze. 2001. Modeling an irrigation management strategy for minimizing the leaching of atrazine. Agr. Water Manage. 48:225-238.

Azevedo, A.S., R.S. Kanwar, and L.S. Pereira. 2000a. Atrazine transport in irrigated heavy- and coarsetextured soils. Part I. Field studies. J. Agric. Eng. Res. 76:165-174.

Azevedo, A.S., R.S. Kanwar, and L.S. Pereira. 2000b. Atrazine transport in irrigated heavy- and coarsetextured soils. Part II. Simulations with the root zone water quality model. J. Agric. Eng. Res. 76:341-354.

Barriuso, E., and S. Houot. 1996. Rapid mineralization of the s-triazine ring of atrazine in soils in relation to soil management. Soil Biol. Biochem. 28:1341-1348.

Barriuso, E., D.A. Laird, W.C. Koskinen, and R.H. Dowdy. 1992. Atrazine desorption from smectites. Soil Sci. Soc. Am. J. 58:1632-1638.

Blake, G.R., and K.H. Hartge. 1986. Bulk density. Chapter 13. In Methods of soil analysis. Part 1. $2^{\text {nd }} \mathrm{ed}$. Agronomy 9. ASA, SSSA, Madison, Wisconsin, USA.

Beck, A., H. Stolting, G. Harris, K.R. Howse, and K. Jones. 1996. Leaching of recently applied and aged residues of herbicides atrazine and isoproturon through a large, structured clay soil core. Chemosphere 33:1297-1305.

Benoit, P., and C.M. Preston. 2000. Transformation and binding of ${ }^{13} \mathrm{C}$ and ${ }^{14} \mathrm{C}$-labelled atrazine in relation to straw decomposition in soil. Eur. J. Soil Sci. 51:43-54. 
Bundt, M., F. Widmer, M. Pesaro, J. Zeyer, and P. Blaser. 2001. Preferential low paths: Biological "hot pots" in soils. Soil Biol. Biochem. 33:729-738.

Cañas, I., S. Hang, M. Nassetta, G. Foray, y N. Reartes. 2000. Una técnica por HPLC para la determinación de atrazina y sus metabolitos hidroxiatrazina, deetilatrazina y deisopropilatrazina, en suelos. XVII Congreso Argentino de la Ciencia del Suelo, Mar del Plata. 11-14 abril 2000.

Cherrier, R., A. Boivin, C. Perrin-Ganier, and M. Schiavon. 2005. Comparison of the leaching behaviour of two maize herbicides: atrazine and sulcotrione. Agron. Sustain. Dev. 25:293-299.

Clay, S.A., D.E. Clay, W.C. Koskinen, and R.K. Berg Jr. 1998. Application method: Impacts on atrazine and alachlor movement, weed control, and corn yield in three tillage systems. Soil Tillage Res. 48:215-224.

Clay, S.A., R.H. Dowdy, J.A. Lamb, J.L. Anderson, B. Lowery, R.E.Knighton, and D.E.Clay.2000.Herbicide movement and dissipation at four midwestern sites. J. Environ. Sci. Health B 35:259-278.

Clay, S.A., and W.C. Koskinen. 1997. Factors affecting atrazine fate in North Central U.S. soils. Rev. Environ. Contam. Toxicol. 151:117-165.

Di, H.J., G.P. Sparling, and G.N. Magesan. 2001. The effect of mineralization rates of atrazine in surface and subsurface soils on its groundwater contamination potential. Aust. J. Soil Res. 39:175-183.

Dousset, S., C. Mouvet, and M. Schiavon. 1995. Leaching of atrazine and some of its metabolites in undisturbed field lysimeters of three soil types. Chemosphere 30:511-524.

Edwards, W.M., M.J. Shipitalo, L.B. Owens, and W.A. Dick. 1993. Factors affecting preferential flow of water and atrazine through earthworm burrows under continuous no-till corn. J. Environ. Qual. 22:453457.

Hang, S.E. Barriuso, and S. Houot. 2003. Behavior of ${ }^{14} \mathrm{C}$-atrazine in topsoils of the Argentinean semi-arid Pampa under different cropping managements. J. Environ. Qual. 32:2216-2222.

Hang, S., E. Barriuso, and S. Houot. 2005. Atrazine behavior in the different pedological horizons of two Argentinean non-till soil profiles. Weed Res. 45:130139.

Hang, S., S. Houot, and E. Barriuso. 2007a. Mineralization of ${ }^{14} \mathrm{C}$-atrazine in a Typic Haplustoll in three winter weed control management. Soil Tillage Res. 96:234242.

Hang, S., M. Nassetta, I.A. Cañas, A. Rampoldi, M.V. Fernández-Canigia, and M. Díaz-Zorita. 2007b. Changes in the atrazine extractable residues in notilled Mollisols. Soil Tillage Res. 96:243-249.
Infostat. 2003. InfoStat v.1.6. Grupo Infostat. Universidad Nacional de Córdoba, Facultad de Ciencias Agropecuarias, Córdoba, Argentina.

Isensee, A.R., and A.M. Sadeghi. 1996. Effect of tillage reversal on herbicide leaching to groundwater. Soil Sci. 161:382-385.

Isensee, A.R., and A.M. Sadeghi. 1997. Interactions of tillage and rainfall on atrazine leaching under field and laboratory conditions. Chemosphere 34:2715-2723.

Kalita, P.K.,A.S.Algoazany, J.K. Mitchell, R.A.C. Cooke, and M.C. Hirschi. 2006. Subsurface water quality from a flat tile-drained watershed in Illinois, USA. Agric. Ecosyst. Environ. 115:183-193.

Koskinen, W.C., and S.A. Clay. 1997. Factors affecting atrazine fate in North central U.S. soils. Rev. Environ. Contam. Toxicol. 151:117-165.

Koskinen, W.C., and E.A. Rochette. 1996. Atrazine sorption-desorption in field-moist soils. Int. J. Environ. Anal. Chem. 65:223-230.

Lerch, R.N., E.M. Thurman, and P.E. Blanchard. 1999. Hydroxyatrazine in soils and sediments. Environ. Toxicol. Chem. 18:2161-2168.

Logan, T.J., D.J. Eckert, and D.G. Beak. 1994. Tillage, crop and climate effects of runoff and tile drainage losses of nitrate and four herbicides. Soil Tillage Res. 30:75-103.

Neurath, S.K, A.M. Sadeghi, A. Shirmohammadi, A.R. Isensee, and A. Torrents. 2004. Atrazine distribution measured in soil and leachate following infiltration conditions. Chemosphere 54:489-496.

Noshadi, M., S. Amin, and N. Maleki. 2002. Measuring atrazine degradation and PRZM-2 testing. Aust. J. Soil Res. 40:643-653.

Pivetz, B.E., and T.S. Steenhuis. 1995. Soil matrix and macropore biodegradation of 2,4-D. J. Environ. Qual. 24:564-570.

Pollock, D., R. Salama, and R. Kookana. 2002. A study of atrazine transport through a soil profile on the Gnangara Mound, Western Australia, using LEACHP and Monte Carlo techniques. Aust. J. Soil Res. 40:455-464.

Sadeghi, A.M., and A.R. Isensee. 1992. Effect of tillage systems and rainfall patterns on atrazine distribution in soil. J. Environ. Qual. 21:464-469.

Sadeghi, A., A.R. Isensee, and A. Shirmohammadi. 2000. Influence of soil texture and tillage on herbicide transport. Chemosphere 41:1327-1332.

Schoen, R., J.P. Gaudet, and T. Bariac. 1999. Preferential flow and solute transport in a large lysimeter, under controlled boundary conditions. J. Hidrol. 215:70-81 .

Sorenson, B., W.C. Koskinen, D. Buhler, D. Wyse, W. Lueschen, and M. Jorgenson. 1994. Formation and movement of ${ }^{14} \mathrm{C}$-Atrazine degradation products in a clay loam soil in the field. Weed Sci. 42:618-624. 
Sorenson, B., D. Wyse, W.C. Koskinen, D. Buhler, W. Lueschen, and M. Jorgenson. 1993. Formation and movement of ${ }^{14} \mathrm{C}$-Atrazine degradation products in a sandy loam soil under field conditions. Weed Sci. 41:239-245.

Sparks, D. (ed.) 1996. Methods of soil analysis. Part 3. Chemical methods. ASA, SSSA, CSSA, Madison, Wisconsin, USA.

Stolpe, N.B., and P.J. Shea. 1995. Alachlor and atrazine degradation in a Nebraska soil and underlying sediments. Soil Sci. 160:359-370.
Tomlin, C. (ed.) 2003. The pesticide manual. The British Crop Production Council (BCPC) Press, Alton, Hampshire, UK.

Zablotowicz, R.M., M.A. Weaver, and M.A. Locke. 2006. Microbial adaptation for accelerated atrazine mineralization/degradation in Mississippi delta soils. Weed Sci. 54:538-547. 